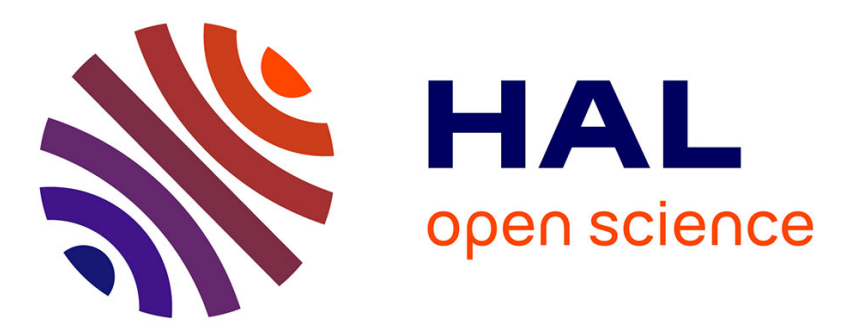

\title{
Isis in Corinth: the Numismatic Evidence. City, Image and Religion
}

\author{
Laurent Bricault, Richard Veymiers
}

\section{To cite this version:}

Laurent Bricault, Richard Veymiers. Isis in Corinth: the Numismatic Evidence. City, Image and Religion. 3rd International Conference of Isis Studies,, 2005, Leiden, Netherlands. pp.392 - 413. hal-01817121

\section{HAL Id: hal-01817121 \\ https://hal.science/hal-01817121}

Submitted on 19 Jun 2018

HAL is a multi-disciplinary open access archive for the deposit and dissemination of scientific research documents, whether they are published or not. The documents may come from teaching and research institutions in France or abroad, or from public or private research centers.
L'archive ouverte pluridisciplinaire HAL, est destinée au dépôt et à la diffusion de documents scientifiques de niveau recherche, publiés ou non, émanant des établissements d'enseignement et de recherche français ou étrangers, des laboratoires publics ou privés. 


\section{Nile into Tiber. Egypt in the Roman World}

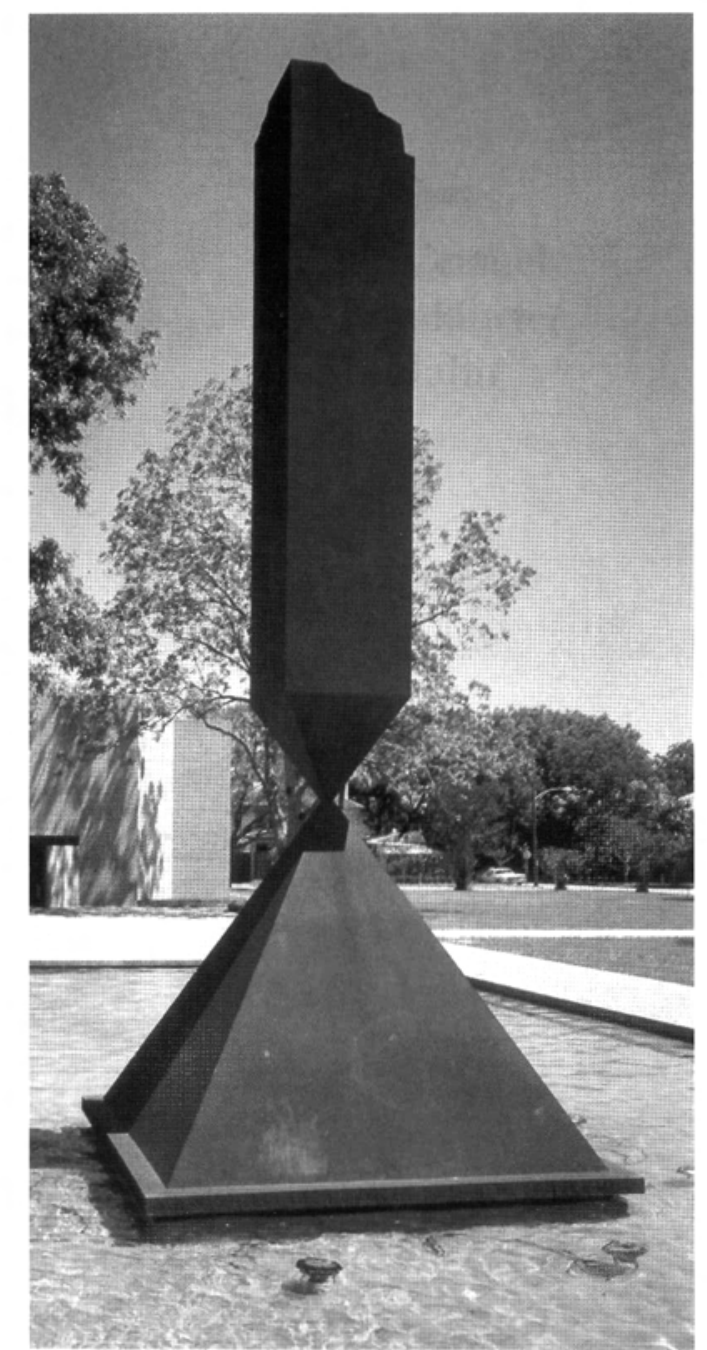

Barnett Newman, Broken obelisk. Sculpture (1967). Houston. (c/o Beeldrecht, Amsterdam)

\section{Proceedings of the IIIrd International Conference of Isis studies, Faculty of Archaeology, Leiden University, May 11-14 2005}

\author{
Edited by \\ Laurent Bricault \\ Miguel John Versluys \\ $\&$ \\ Paul G.P. Meyboom

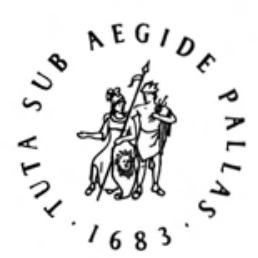 \\ B R I L L
}


This series Religions in the Graeco-Roman World presents a forum for studies in the social and cultural function of religions in the Greek and the Roman world, dealing with pagan religions both in their own night and in their interaction with and influence on Christianity and fudaism during a lengthy period of fundamental change. Special attention will be given to the religious history of regions

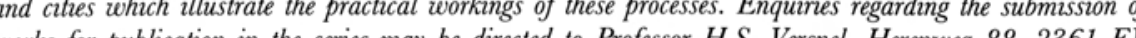
Versnel, Herenweg 88, 2361 EV Warmond, The.Netherlands, h.s.versnel@hetnet.nl.

This book is printed on acid-free paper.

\section{Library of Gongress Cataloging-in-Publication Data}

A C.I.P. record for this book is available from the Library of Congress.

ISSN $\quad 0927-7633$

ISBN 10: 9004154205

ISBN 13: 9789004154209

(c) Gopyright 2007 by Koninklijke Brill NV, Leiden, The Netherlands

Koninklijke Brill NV incorporates the imprints Brill,

Martinus Nijhoff Publishers and VSP.

All rights reserved. No part of this publication may be reproduced, translated, stored in a retrieval system, or transmitted in any form or by any means, electronic, mechanical, photocopying, recording or otherwise, without prior written permission from the publisher.

Authorization to photocopy items for internal or personal use is granted by Brill provided that

the appropriate fees are paid directly to The Copyright

Clearance Center, 222 Rosewood Drive, Suite 910

Danvers, MA 01923, USA.

Fees are subject to change.

\section{CONTENTS}

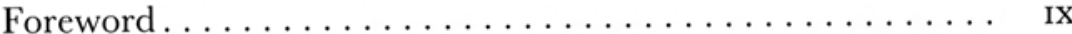

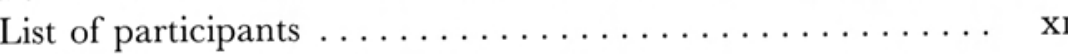

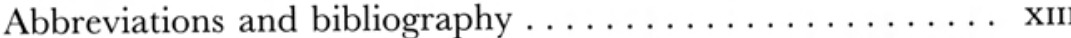

List of figures. . . . . . . . . . .

Aegyptiaca Romana: The widening debate $\ldots \ldots \ldots \ldots \ldots$

Miguel John Versluys

\section{Interpretations of the meaning of Aegyptiaca Romana}

Theoretical reflections: The role of Egypt and Egyptian religion in the Roman world

La diffusion des cultes isiaques: Un problème de terminologie

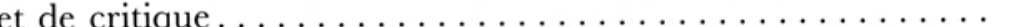

Michel Malaise

The Hellenistic face of Isis: Cosmic and saviour goddess . . . .

Giulia Sfameni Gasparro

Isis gréco-romaine et l'hénothéisme féminin

ROBERT TURCAN

Dion Cassius et les phénomènes religieux "égyptiens".

Quelques suggestions pour un mode d'emploi..........

Pierre Cordier

\section{Case studies: Aegyptica in and around Pompeii and}

\section{Rome}

Egyptian objects, Roman contexts: A taste for aegyptiaca in

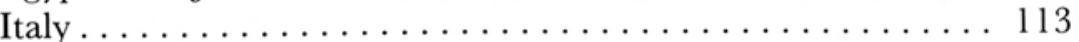

Molly Swetnam-BuRLAND

The temple of Isis at Pompeii 9

Fes

Eric M. Moormann 
Three uses of the pygmy and the Aethiops at Pompeii:

Decorating, "othering", and warding off demons ........ 155 John R. CLARKe

The meaning of dwarfs in Nilotic scenes . . . . . . . . . 170

Paul G.P. Meyboom \& Miguel John Versluys

Obelisks still in exile: monuments made to measure? . . . . . . 209 Grant Parker

A literary view on the Nile mosaic at Praeneste

Piet H. SGhrijvers

\section{Understanding the cults of Isis in their local context}

\section{The Balkans \& Greece}

La diffusion isiaque en Mésie Inférieure et en Thrace:

Politique, commerce et religion ............... 245

LaUrent Brigault

Témoignages isiaques en Dacie (106-271 ap. J.-C.): Cultes et

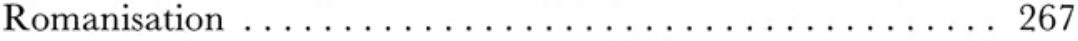

Marie-Christine Budischovsky

Traces d'Égypte en Dalmatie romaine: Culte, mode et

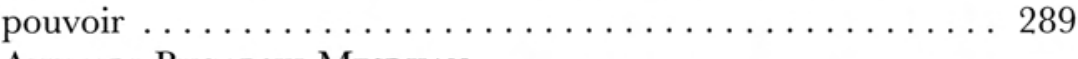

Anemari Bugarski-Mesdjian

Cultes et divinités isiaques en Thessalie: Identité et urbanisation. ............................ 329 Jean-Claude Degourt \& Athanassios Tziafalias

Egyptian cults and local elites in Boiotia .. 364

Albert Schachter

Isis in Corinth: the numismatic evidence. City, image and religion. ................................ 392

Laurent Bricault \& Richard Veymiers

\section{The Aegean \& Eastern Mediterranean}

L'Hydreion du Sarapieion C de Délos: la divinisation de l'eau dans un sanctuaire isiaque ................... 417 HÉLÈNE SIARD

Les dévotions à Isis et Sérapis dans la Judée-Palestine romaine ................................. 448 Nicole Belayche

Images of Isis and her cultic shrines reconsidered. Towards an Egyptian understanding of the interpretatio graeca ....... 470 Robert Steven Bianchi

The temple at Ras el-Soda. Is it an Isis temple? Is it Greek, Roman, Egyptian, or neither? And so what?.......... 506 FREDERICK G. NAEREBout

Indices . 


\section{ISIS IN GORINTH: THE NUMISMATIC EVIDENCE. CITY, IMAGE AND RELIGION}

Laurent Bricault \& Richard Veymiers

Isiac types present in the coinage of continental and insular Greece are very dispersed geographically and very condensed chronologically. ${ }^{1}$ Such examples are found only in Macedonia at Amphipolis, Stobi, Apollonia, and possibly Dyrrhachium; in Thessaly at Hypata; in Megarid at Pagai; in Attica at Athens, Aegina; in the Cyclades at Syros; and lastly, on the Peloponnesus. Except for the very specific case of Patras, no Isiac trace is observed in the Peloponnesian issues dating from the Hellenistic period. ${ }^{2}$ During the second and third centuries A.D., however, one or several Isiac types were used by at least thirteen of the forty-five cities and small towns striking their own coinage on the peninsula, including Aigeira, Aigion, Argos, Asine, Boiai, Cleonai, Corinth, Heraia, Mothone, Pheneos, Phlius, Sicyon, and Thelpusa. ${ }^{3}$ Of these, Argos and Corinth are noted for the survival of a significant number of issues presenting Isiac types. It's to the coinage of the latter city, from which the richest and most varied examples survive, that we devote the following few pages.

\footnotetext{
1 Our thanks to Heather Egan for her help with the English translation.
2 Patras is known for at least one issue under the name of Cleopatra, struck on the occasion of Anthony's presence in this harbor town during the winter of $32 / 31$. On the obverse the portrait of the Ptolemaic queen is accompanied by the legend ВАCIAICCA КАЕОПАТРA, while on the reverse the basileion of Isis is represented. If the legend in the nominative is distinguished from the legends used on Alexandrian coinage of the queen, which always use the genitive, the Patras issue can be compared to the joint issue struck at Antioch in 36 B.C. under the names of Anthony and Cleopatra. The basileion on the reverse, in the present case, recalls that the queen had assumed the role of Nea Isis since 34 B.C. See: SNRIS (L. Bricault dir.), forthcoming.

3 This figure really needs to be re-evaluated, as these coins are rarely published and seldom studied. There is no doubt that more thorough research of the large
} numismatic collections would reveal many new examples.

\section{Hadrian \\ 117-138 A.D.}

AE, 20-23 mm (3 ex.), $8.34 \mathrm{~g}$ (1). Axis: 5:00 (1) (= SNRIS Corinthus 1)

\section{Type 1: Isis standing}

Obv.: IMP C NE TRAI[...], laureate and draped bust of Hadrian r.

Rev.: COL L IVL COR, Isis standing r., brandishing the sistrum in her right hand and holding the situla in her lowered left.

1.

(a) London (1920 8-5-941) [-/20/-].

(b) Bern; SNG Righetti 456 [8.34/22/5].

(c) Mus. H. Arigoni I, 95.39; D. Sestinius, Catalogus Numorum veterum musei Arigoniani (Berolini 1805) 37; Mionnet, Suppl. 4 81.546; Cohen 2 237.1536; Fr. Imhoof-Blumer, P. Gardner, fHS 6 (1885) 74 pl. F-CXIX; Fr. Imhoof-Blumer, P. Gardner, A Numismatic Commentary on Pausanias (London 1887) 25.31 pl. F-CXIX (abbreviated afterwards $\mathcal{N} C P$ ); Dunand, Culte d'Isis II pl. XLV-2; D. E. Smith, The Egyptian Cults at Corinth, HThR 70 (1977) 221 n. $62[-/ 20-23 /-]$ (fig. 1).

(d) E. Lévy, Sondages à Lykosoura et date de Damophon, $B C H 91$ (1967) 532 and fig. 25537 [-/22-23/-].

\section{Antoninus \\ 138-161 A.D.}

AE, 23-26 mm, 13.98 g. (6 ex.). Axis: 2:00 (1), 5:00 (1), 6:00 (3) (= SNRIS Corinthus 2)

\section{Type 2: Isis sailing}

Obv:: ANTONINVS AVG PIVS, laureate head of Antoninus r. Rev.: CLI GOR, Isis Pelagia standing r., wearing a basileion and peplos, 


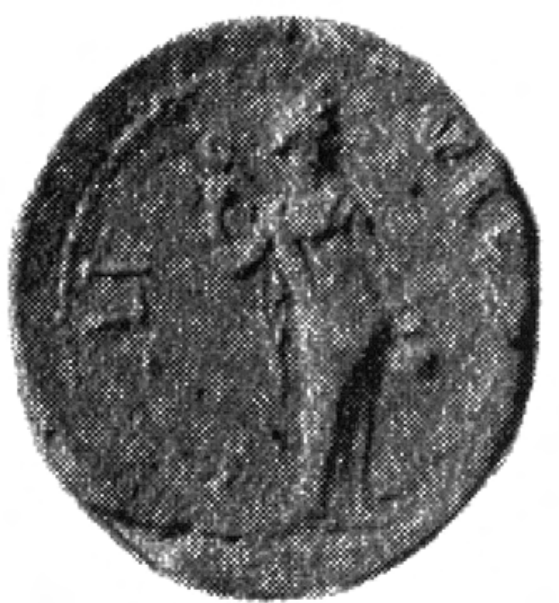

Fig. 1. Aes. Hadrianus (from F. Dunand, Culte d'Isis II, pl. XLV-2).

which flutters out behind her, and holding in front a billowing sail with her two hands and left foot.

2.

(a) Paris (865); Mionnet, Suppl. 4 88.592; Cohen 2 400.1213; Smith, Egyptian Cults 221-222, n. 64 [15.01/25/6].

(b) London (1920 8-5-997) [13.28/23/6].

c) New York (1944-100-38562) [12.28/-/2].

d) Berlin (Löbbecke 1906) [13.16/25/6].

(e)* Münzzentrum Rheinland 101 (1999), 219 [15.00/26/-] (fig. 2).

(f) Lanz 105 (2001) 656; Münzzentrum Rheinland 110 (2002) 196; Jacquier 30 (2003) 212 [14.79/26/5].

AE, 26 mm, 10.32 g (2 ex.). Axis: 9:00 (1), 10:00 (1) (= SNRIS Corinthus 3)

\section{Type 3: Harbor of Kenchreai}

Obv.: ANTONINVS AVG PIVS, laureate and draped bust of Antoninus, $r$.

Rev.: CLI COR, view of the harbor of Kenchreai- suggested by a

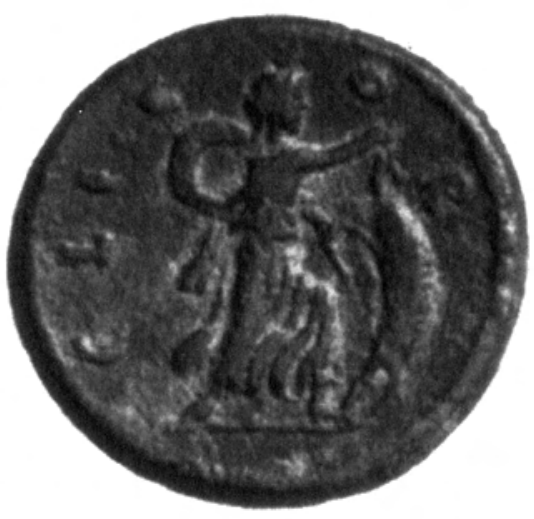

Fig. 2. Aes. Antoninus Pius (Priv. Coll.)

long and semicircular quay, perhaps skirted by a colonnade - with Isis Pelagia, standing r., in its center. On the l., at the end of the quay, is a statue of Poseidon shown frontally in his distyle temple, while on the $\mathrm{r}$. at the other end is a temple in three-quarter view towards the 1. Above the hemicycle of the harbor, an arched outgrowth corresponds perhaps to a second floor sheltering a sculpture.

3.

(a)* London; M. J. Price and B. L. Trell, Coins and their Cities. Architecture on the ancient coins of Greece, Rome, and Palestine (London 1977) 83 fig. 146 [-/26/-] (fig. 3).

(b) Berlin (Löbbecke 1906); K. Lehmann-Hartleben, Die antiken Hafenanlagen des Mittelmeeres, Klio Beiheft 14 (Leipzig 1923) 238 Münztafel no. 11; J. Leipoldt and K. Regling, Archäologisches zur Isis-Religion, АГГЕ $O \mathrm{O}$. Archiv für Neutestamentliche Zeitgeschichte und Kulturkunde I (1925) 130 pl. 5.3; R. L. Hohlfelder, Pausanias, II, 2, 3: A Collation of Archaeological and Numismatic Evidence, Hesperia 39 (1970) 328 n. 10 pl. 80/c; Smith, Egyptian Cults 202203 [12.77/26/9].

c) Corinth (Hemicycle, 19.12.1929-145); K. M. Edwards, Coins $1896-$ 1929 (Corinth, VI) (Cambridge 1933) 32.149 [7.88/26/10].

AE, 20 mm, 4.81 g (1 ex.). Axis: 3:00 (1) (= SNRIS Corinthus 4) 


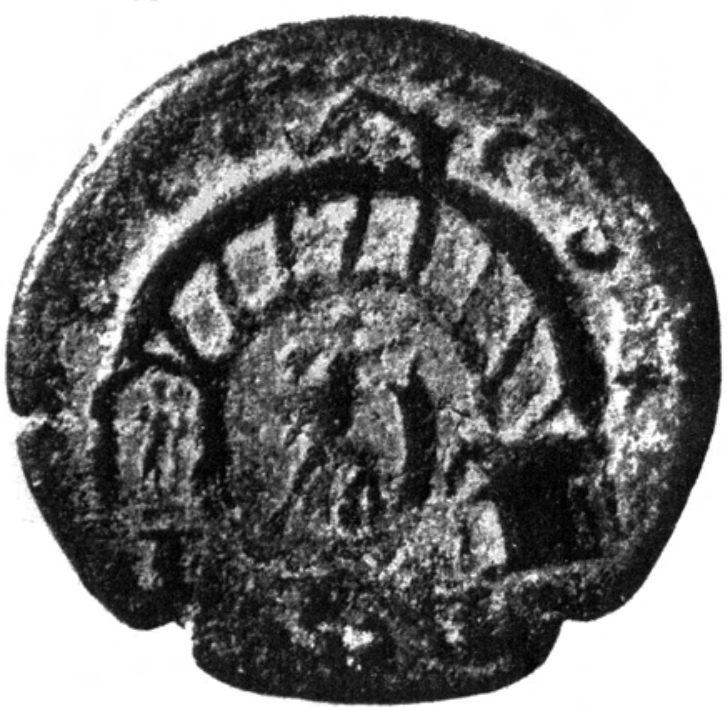

Fig. 3. Aes. Antoninus Pius (from M. J. Price and B. L. Trell, Coins and their Cities Architecture on the ancient coins of Greece, Rome, and Palestine, London 1977, p. 83 fig. 146).

\section{Type 1: Isis standing}

Obv.: ANTONINVS [AVG PIVS], laureate head of Antoninus, r. Rev.: CLI COR, Isis standing l., brandishing the sistrum in her right hand and holding the situla in her lowered left.

4.

(a)* Lanz 105 (2001), 676 [4.81/20/3] (fig. 4).

\section{Lucius Verus and Marcus Aurelius}

\section{a. Lucius Verus}

161-169 A.D.

AE, 26 mm, 12.12 g (5 ex.). Axis: 3:00 (1), 10:00 (4) (= SNRIS Corinthus 5)

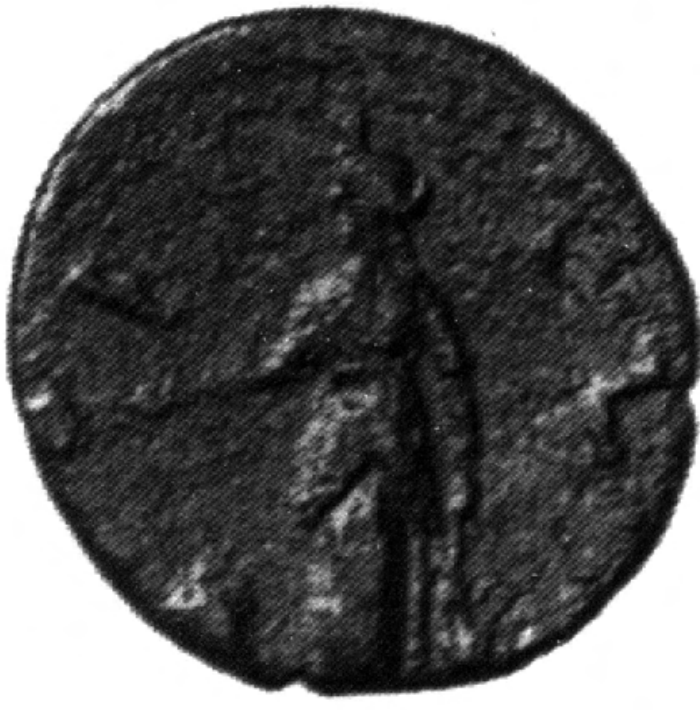

Fig. 4. Aes. Antoninus (Priv. Coll.).

\section{Type 2: Isis sailing}

Obv.: IMP L AVR VERVS AVG, laureate and draped bust of Lucius Verus, $r$.

Rev.: CLI COR, Isis Pelagia standing r., wearing a basileion and peplos, which flutters out behind her, and holding in front a billowing sail with her two hands and left foot.

5.

(a) New York (1944-100-38591) [10.12/-/10].

(b)* Berlin (Imhoof-Blumer 1900); Imhoof-Blumer, Gardner, FHS 6 66, pl. D-LXIV; Fr. Imhoof-Blumer, P. Gardner, $\mathcal{N} C P$ (London 1887) 17.11 pl. D-LXIV; Dunand, Culte d'Isis II pl. XLV-1; Smith, Egyptian Cults 222 n. 65 [11.45/26/10] (fig. 5).

(c) Malloy XXIII (1987) 162; Lanz 105 (2001) 746; Künker 97 (2005) 1543 [12.24/26/3].

(d) Athens (4034) [13.45/26/10].

(e) Corinth (Panaghia Field, 23.05.2001-121) [13.39/26/10]. ${ }^{4}$

4 Our thanks to Orestes H. Zervos for bringing this specimen to our atten- 




Fig. 5. Aes. Lucius Verus and Marcus Aurelius (Berlin. Imhoof-Blumer 1900).

\section{b. Marcus Aurelius}

161-180 A.D.

AE, 9.62 g (1 ex.). Axis: 12:00 (1) (= SNRIS Corinthus 6)

\section{Type 2: Isis sailing}

Obv.: (M AVR ANTONINVS AVG?), laureate head (?) of Marcus Aurelius, $\mathrm{r}$.

Rev.: CLI COR, Isis Pelagia standing r., wearing a basileion and peplos, which flutters out behind her, and holding in front a billowing sail with her two hands and left foot.

6.

(a) New York (1944-100-38581) [9.62/-/12].

\section{Commodus}

177-192 A.D.

AE, 26 mm, 9.33 g (1 ex.). Axis: 4:00 (1) (= SNRIS Corinthus 7)

\section{Type 4: Sarapis seated}

Obv.: [...] COMMODVS ANTONINVS, laureate, draped, and cuirassed bust of Commodus, $r$.

Countermark: laureate head of an emperor, $r$.

Rev.: CLI COR, Sarapis seated l., wearing the calathos, holding a sceptre in his left hand, his right stretched above Cerberus.

7.

(a)* Lanz 105 (2001) 776 [9.33/26/4] (fig. 6).

\section{Septimius Severus, Julia Domna, and Plautilla}

\section{a. Septimius Severus 193-211 A.D.}

AE, 25 mm, 7.11 g (1 ex.). Axis: 6:00 (1) (= SNRIS Corinthus 8a)

\section{Type 2: Isis sailing}

Obv.: SEPT CEVE[...], laureate head of Septimius Severus, r.

Countermark: head, $r$.

Rev.: CL[T COR, Isis Pelagia standing r., wearing a basileion and peplos, which flutters out behind her, and holding in front a billowing sail with her two hands and left foot, and in addition, a sistrum in her right hand.

8.

(a) Lanz 105 (2001) 837 [7.11/25/6].

AE, 27 mm, 9.90 g (1 ex.). Axis: 10:00 (1) (= SNRIS Corinthus 8b)

Obv.: SEPT CEVE[...], laureate and draped bust of Septimius Severus, $r$.

Rev.: Same description as the previous example.

9.

(a)* Vecchi 7 (1997) 1361; Lanz 105 (2001) 836 [9.90/27/10] (fig. 7). 


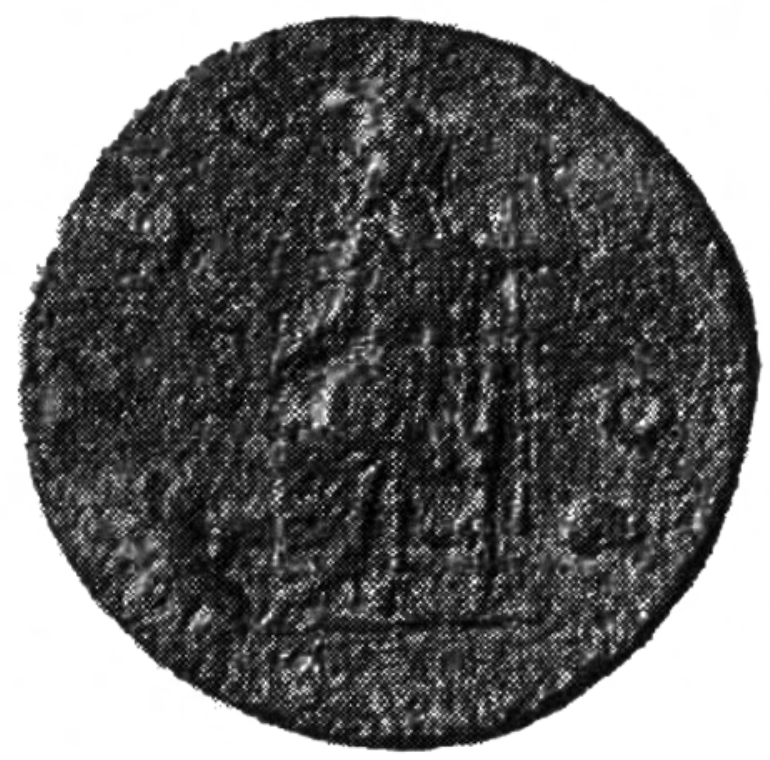

Fig. 6. Aes. Commodus. (Priv. Coll.).

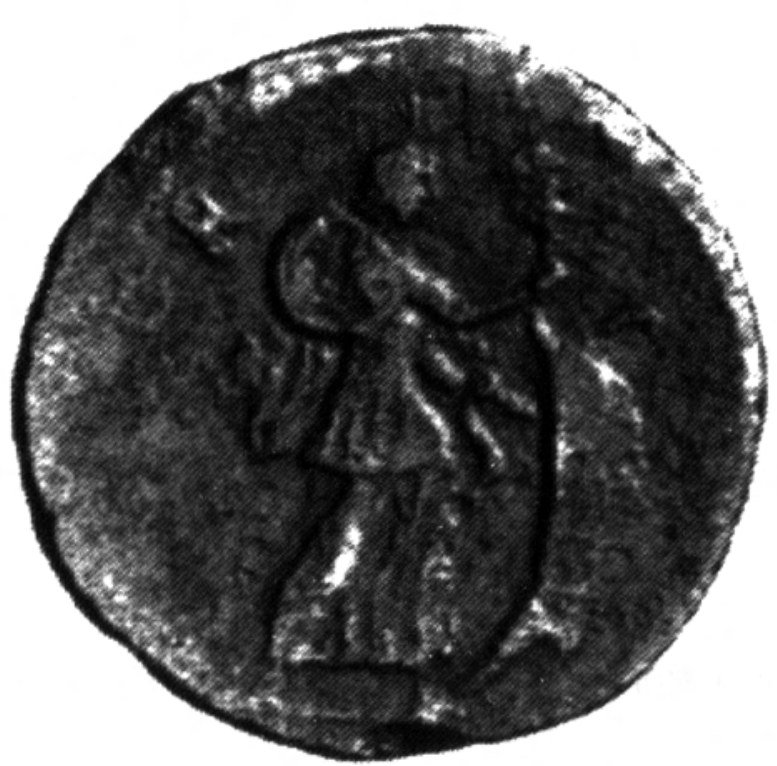

Fig. 7. Aes. Septimius Severus (Priv. Coll.).

\section{b. Julia Domna ${ }^{5}$ \\ 193-217 A.D.}

AE, 23 mm, 5.68 g (1 ex.). Axis: 7:00 (1) (= SNRIS Corinthus 9)

\section{Type 2: Isis sailing}

Obv.: IVLIA [DOMNA ...], draped bust of Julia Domna, r.

Rev.: CLI COR, Isis Pelagia standing r., wearing a basileion and peplos, which flutters out behind her, and holding in front a billowing sail with her two hands and left foot.

10.

$(\mathbf{a})^{*}$ Berlin (Löbbecke 1906) [5.68/23/7] (fig. 8).

\section{c. Plautilla} 202-205 A.D.

AE 23-24 mm, 7,27 g (3 ex.). Axis: 6 h (1), 7 h (1) (= SNRIS Corinthus 10)

\section{Type 2: Isis sailing}

Obv.: PLAVTILLA AVG [...], draped bust of Plautilla, r.. Rev.: CLI COR, Isis Pelagia standing r., wearing a basileion and peplos, which flutters out behind her, and holding in front a billowing sail with her two hands and left foot.

11.

(a) London (1920 8-5-1159) [11.59/23/6] (fig. 9).

(b) Coll. LB; Lanz 105 (2001) 955 [5.61/23/7].

(c) L. Forrer, The Weber Coll. 404.3811 pl. 140; Smith, Egyptian Cults 222 n. $66[4.60 / 24 /-]$.

(d) Cohen 4250.40 [-/-/-].

5 The description of a coin cited by Mionnet in Suppl. $4119.815=$ Mus. $H$. Arigoni II [1744] col. 10, 100) needs to be corrected. On this Corinthian issue of Julia Domna he recognized "Sérapis à demi nu, ou un Génie debout, à g., devant un autel, tenant une patère de la main dr., et une corne d'abondance de la g." It certainly is not Sarapis, but rather the Genius of the colony, who is represented. 


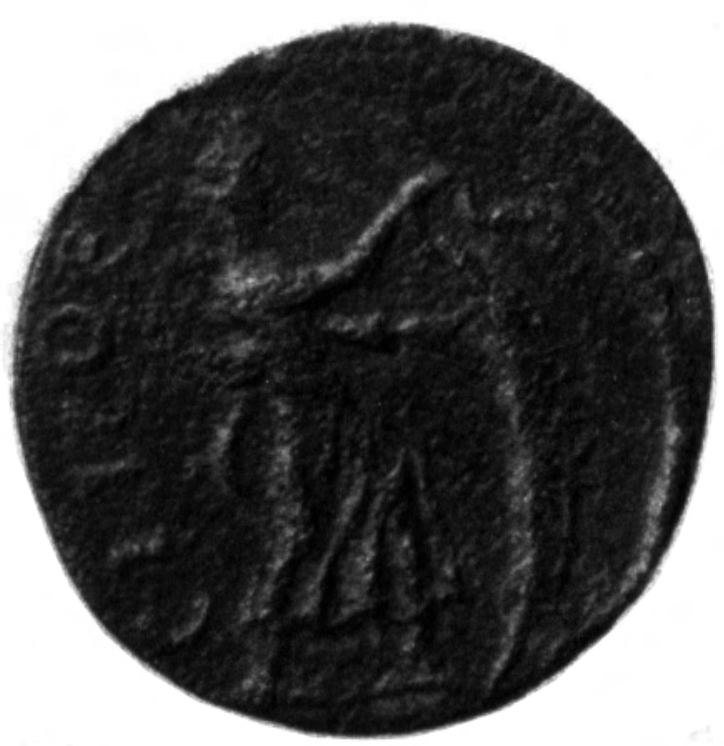

Fig. 8. Aes. Julia Domna (Berlin. Löbbecke 1906).

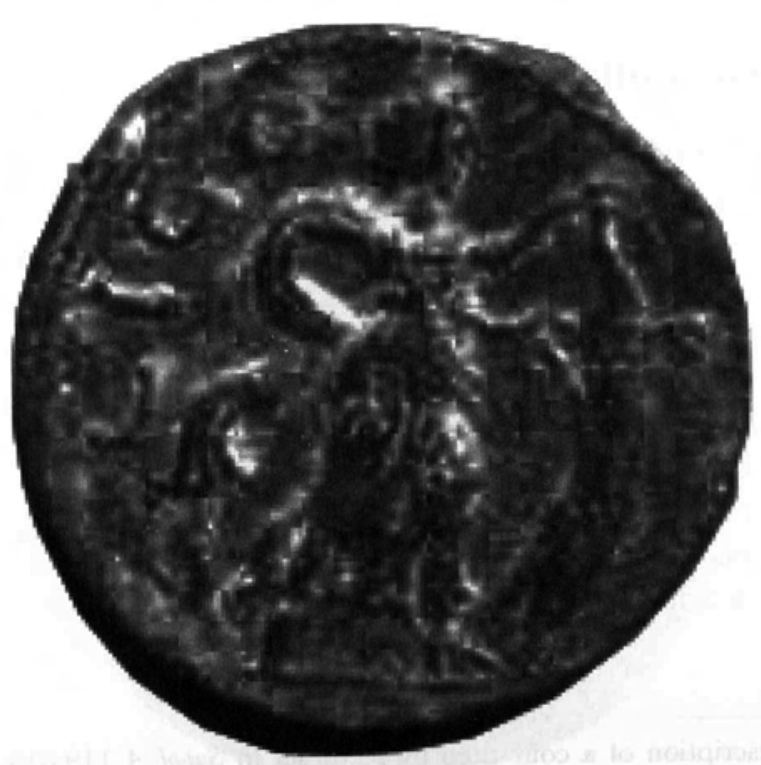

Fig. 9. Aes. Plautilla (London 1920 8-5-1159).
The Isiac Cults at Corinth: The Contribution of the Coins

Our knowledge of the Isiac presence at Corinth and in its two harbors of Kenchreai and Lechaion is very fragmented. Rare inscriptions ${ }^{6}$, some illustrated documents ${ }^{7}$, two passages of Pausanias (2.2.3 and 2.4.6), and a famous text by Apuleius (Méta. XI, 16) hardly give a complete outline of the cult of Isis and the divinities of her circle in this metropolis of the Peloponnesus. ${ }^{8}$ The contribution of the coinage, so often ignored, therefore is well worth considering.

According to our research, Isiac types first appear under Hadrian and continue until the first Severans a century later. ${ }^{9}$ Four different types were used after the reopening of the mints under Domitian ${ }^{10}$ : Isis

${ }^{6}$ RICIS 102/0101, 102/0102, and *102/0201

7 The precise references concerning most of these documents are found in Bricault, Atlas 8 . To Bricault's list may be added a steatite statuette with the effigy of Osiris Hydreios (Ch. K. Williams II and O. H. Zervos [Corinth 1984]: East of the Theater, Hesperia 54 [1985] 79-80.49 pl. 17); a boat-shaped lamp decorated with a bust of Isis (O. Broneer, Terracotta Lamps, Corinth, IV/2 [Cambridge 1930] $284.1448 \mathrm{pl}$. 21); and some sculpture fragments belonging to representations of Isis or Isiac(s?) (F. P. Johnson, Sculpture, 1896-1923, Corinth, IX [Cambridge 1931] 68.123; and M. C. Sturgeon, Sculpture: The Assemblage from the Theater, Corinth, IX/3 [Athens 2004] $205.88 \mathrm{pl} .72 / \mathrm{b}-\mathrm{c}$ ). The lamp in the Hermitage Museum (O. Waldhauer, Kaiserliche Ermitage. Die antiken Tonlampen [St. Petersburg 1914] 312 pl. 33) is neither of Corinthian provenance nor manufacture and thus should be eliminated from Bricault's list.

8 Equally relevant are the comments of Dunand, Culte d'Isis II 17-18 and 157160; D. E. Smith, The Egyptian Cults at Corinth, HThR 70 (1977) 201-231; and L. Bricault, Isis, Dame des flots (forthcoming). R. Veymiers is preparing a general study on the Isiac diffusion in the Peloponnesus within the framework of a doctoral dissertation.

${ }_{9}$ Several scholars have discussed Isiac coinage from Corinth under the reign of Trajan, referring to a coin on which T. E. Mionnet recognized the head of Plotina with the legend PLOTINA AVGVSTA on the obverse, and Isis sailing with the legend CLI COR on the reverse (see: Mionnet 2 179.226; Cohen 2 98.15; Fr. Imhoof-Blumer, P. Gardner, 7HS 6 [1885] 66; Fr. Imhoof-Blumer, P. Gardner, $\mathcal{N} C P$ [London 1887] 17.11; Dunand, Culte d'Isis II 158; and Smith, Egyptian Cults 221 n. 63). However, due to the absence of other issues of Plotina from Corinth-and in fact from the whole of the Peloponnesus-we seriously doubt this attribution and suggest that Mionnet confused two empresses, seeing Plotina where he should have recognized Plautilla accompanied by the legend PLAVTILLA AVGVSTA Certainly, coins showing Isis sailing with the legend CLI COR on their reverse side are well attested under Plautilla (cf. our series 11). Let us note, finally, that the legend CLI COR first appeared during the Principate of Antoninus.

${ }^{10}$ For a list of iconographical types in use at Corinth during the Imperial Period, see: H. Papageorgiadou-Bani, The Numismatic Iconography of the Roman colonies 
standing, Isis sailing, Sarapis seated, and Isis sailing in the Kenchreai harbor.

\begin{tabular}{|l|l|l|l|l|}
\hline & Isis Standing & Isis Sailing & $\begin{array}{l}\text { Sarapis } \\
\text { Seated }\end{array}$ & $\begin{array}{l}\text { Harbor of } \\
\text { Kenchreai }\end{array}$ \\
\hline Domitian & & & & \\
\hline Trajan & & & & \\
\hline Hadrian & $\mathrm{x}$ & & & \\
\hline Sabina & & & & \\
\hline Antoninus & $\mathrm{x}$ & $\mathrm{x}$ & & $\mathrm{x}$ \\
\hline Marcus Aurelius & & $\mathrm{x}$ & & \\
\hline Lucius Verus & & $\mathrm{x}$ & & \\
\hline Commodus & & & $\mathrm{x}$ & \\
\hline Septimius Severus & & $\mathrm{x}$ & & \\
\hline Julia Domna & & $\mathrm{x}$ & & \\
\hline Caracalla & & & & \\
\hline Plautilla & & $\mathrm{x}$ & & \\
\hline Geta & & & & \\
\hline
\end{tabular}

The table shows us that the Isiac coins are of great interest on account of the long duration of their use and the relative diversity of the selected types. Nevertheless, the low number of known specimens prompts us to acknowledge that the Isiac types are under-represented proportionately in comparison with other Corinthian types that at the time were much more in vogue (such as Aphrodite, Poseidon, Bellerophon, and Melikertes/Palaimon). ${ }^{11}$

The first type is that of Isis standing with a basileion on her head, a sistrum in her raised right hand, and a situla in her lowered left. It first appears under Hadrian and continues under Antoninus

in Greece. Local Spirit and the Expression of Imperial Policy, Meletimata 39 (Athens 2004) 103-118, who offers a non-exhaustive list.

${ }^{11}$ For information regarding the Corinthian coinage issued under the Flavians and the Antonines, see: M. E. Hoskins Walbank, Aspects of Corinthian Coinage in the Late 1st and Early 2nd Centuries A.D., in: Ch. K. Williams II and N. Bookidis (eds.), Corinth, the Centenary: 1896-1996, Corinth XX, American School of Classical Studies at Athens (2003) 337-349. before being finally supplanted by that of the Pelagia type. This is the image of the goddess most often used on the coins of other Peloponnesian cities - at Argos from Hadrian's reign until that of Severus Alexander, and also under the reign of the first Severans at Boiai, Cleonai, Heraia, Mothone, Sicyon, and Thelpusa. ${ }^{12}$ As recalled by V. Tran tam Tinh, this iconographic type, often wrongly regarded as "canonical", appeared probably not before the late first or the early second century A.D. ${ }^{13}$ It can hardly have been as defined as the Hellenised Isis, who carries a cornucopia and sceptre, but neither the sistrum, nor the situla. This more "Egyptian" type could well have been that used for the statue decorating the temple of Isis referred to by Pausanias as Aigyptia. ${ }^{14}$

The second type always refers to Isis, but presents her under the features of the Pelagia, that is, the sovereign of the seas. It was used from the time of Antoninus to that of Caracalla, with a short interlude under Commodus, and always shows the goddess standing with the basileion, wearing a peplos that flutters out behind her, and holding a billowing sail in her two hands. Under Septimius Severus (our series 8 and 9) Isis holds a sistrum in her right hand, in addition to the sail, thereby recalling our first type. This iconography, very popular at Corinth, surprisingly is found only in the Peloponnesus at Cleonai under Caracalla. ${ }^{15}$ It could well be that of the statue of the temple of Isis described by Pausanias as Pelagia. ${ }^{16}$

12 References are given for one specimen of each issue. Argos: Imhoof-Blumer, Gardner, NCP 42.30 (Hadrian); and SNG Cop. Argolis no. 106 (Severus Alexander). Boiai: Imhoof-Blumer, Gardner, NCP 64 pl. O.15 (Julia Domna). Cleonai: SNG Tübingen pl. 71.1974 (Plautilla). Heraia: Numismatic Museum of Athens 4533 (Julia Domna). Mothone: BMC Pelop. 117.3 pl. 23.17 (Julia Domna) and 117.5 pl. 23.19 (Plautilla) Sicyon: Coll. Lindgren 79.1633 (Plautilla); and Imhoof-Blumer, Gardner, NCP 158 (Geta). Thelpusa: Mionnet, Suppl. 4295.124 (Septimus Severus); and Numismatic Museum of Athens 544 (Geta?).

${ }^{13}$ Tran tam Tinh, Etudes iconographiques 1725-1726.

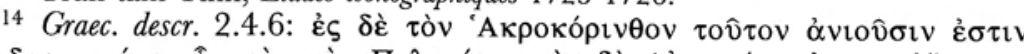

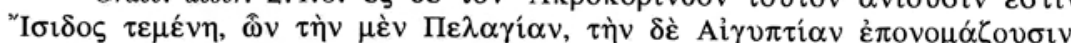


Acrocorinthus you see two precincts of Isis, one of Isis surnamed Pelagian (Marine) and the other of Egyptian Isis, and two of Serapis, one of them being of Serapis called 'in Canopus."'

${ }^{15}$ L. Forrer, The Weber Coll. 480.4215 pl. 154.

16 A statue recently discovered at Messene may confirm this $(\mathrm{P}$. Thémélis, [2002] 27-28 pls. 17, 20-22). Here the iconography of Isis sailing seems to have 
Before commenting on the third type, which again takes up the iconography of Isis sailing yet places it in an architectural context in the center of the Kenchreai harbor, let us highlight the brief appearance of Sarapis on an issue from Commodus's reign (our type 4). The consort of Isis is pictured here in his most frequent form: seated on a throne with a calathos on his head, holding a sceptre in his left hand and lowering his right to Cerberus, seated at his feet. Until now this image - attested also at Argos under Antoninus, as well as at Pheneos and Sicyon under the Severans-remains restricted at Corinth to the reign of Commodus. ${ }^{17}$ However, it's precisely under this emperor that the type of Isis sailing experiences a short interruption. Sarapis, therefore, seems to have overtaken Isis during the reign of an emperor whose preference for the god is well known. ${ }^{18}$

The most interesting monetary type is our type 3 , known by an issue under the name of Antoninus (our series 3), which can be compared with a passage of Pausanias (2.2.3):

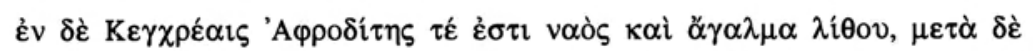



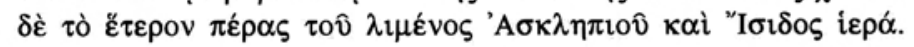

"In Cenchreae are a temple and a stone statue of Aphrodite, after it on the mole running into the sea a bronze image of Poseidon, and at the other end of the harbor sanctuaries of Asclepius and of Isis."

Especially interesting for our study is a Corinthian coin published in 1812 by M. Millingen. ${ }^{19}$ Struck under the name of Antoninus, it

been translated into sculpture in the round, contrary to the thesis defended by $\mathrm{Ph}$. Bruneau, Existe-t-il des statues d'Isis Pélagia?, BCH 98 (1974) 333-381. For a review of the state of the question, see: Bricault, Isis, Dame des flots (forthcoming).

17 Argos: BCH 78 (1954) 186 fig. 52/5, 188.5e. Pheneos: Mionnet 2, 252-253.55 (Plautilla); and S. Boutin, Coll. Pozzi (Maastricht 1979) 236.4360 pl. 192 (Caracalla). Sicyon: Imhoof-Blumer, Gardner, NCP 31.14 (Septimius Severus, Plautilla, Geta).

${ }_{18}$ Unless there is simply a gap in our documentation. On Commodus and Sarapis, see among others: Malaise, Conditions 432-436; and L. Bricault, Présence isiaque dans le monnayage impérial romain, in: F. Lecocq (ed.), L'Égypte à Rome. Actes du colloque international de Caen 28-30.11.2002, Cahier de la MRSH-Caen 41 (Caen 2005) 96-98.

${ }_{19}$ M. Millingen, Recueil de quelques médailles grecques inédites (Rome 1812) $46.2 \mathrm{pl}$. II.19; Mionnet, Suppl. 4 88.593; Imhoof-Blumer, Gardner, 7HS 666 pl. D-LX;

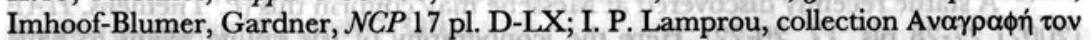

shows on its reverse side a harbor in a semicircular arrangementsuggested by a long quay perhaps bordered by a colonnade-at the ends of which are two temples. The tetrastyle temple on the left, flanked by a tree, is represented frontally, while the other temple is shown simply in three-quarter view to the right. The three ships sailing outside the entrance to the harbor serve as the symmetrical counterpart of the hemicycle. A statue of Poseidon is seen in the center of the composition; he is naked, armed with his trident, and accompanied by a dolphin. Above this iconography is the legend C(olonia) L(aus) I(iulia) Cor(inthus). There's been a lot of ink spilled and often ingenious assumptions made in order to account for the differences between this picture and Pausanias' description, far more so than for the similarities. The identification of this port with that of Kenchreai is without doubt for most scholars, as the similarities between image and text are evident. ${ }^{20}$ The major difference

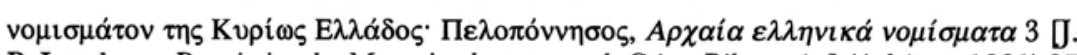
P. Lambros, Description des Monnaies du royaume de Grèce, Péloponnèse] (Athènes 1891) 27 pl. G fig. 9; A. A. Boyce, The Harbor of Pompeiopolis. A Study in Roman Imperial Ports and Dated Coins, AfA 62 (1958) pl. 13.4; and Dunand, Culte d'Isis II pl. XLV3. A second example, housed in Berlin, was published by K. Lehmann-Hartleben, Die antiken Hafenanlagen des Mittelmeeres, Klio Beiheft 14 (Leipzig 1923) 238 Münztafel no. 10 (and again by J. Leipoldt, K. Regling, Archäologisches zur Isis-Religion,

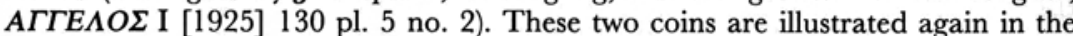
article of R. L. Hohlfelder, Pausanias, II, 2, 3: A Collation of Archaeological and Numismatic Evidence, Hesperia 39 (1970) pl. 80 a-b. A third specimen is kept in the Numismatic Museum of Athens (4025). On two others that belong to private collections, see: S. Boutin, Coll. Pozzi (Maastricht 1979) no. 3859; and the catalogue by the auction house Numismatik Lanz München no. 105 (2001) no. 667.

${ }^{20}$ Only E. Walde (Die Aufstellung des aufgestützten Poseidon, AM 93 [1978] 106) disputes this identification, preferring to see instead the other harbor of Corinth, the Lechaion, which thereby enabled her to attach the statue of Kenchreai to its "aufgestützten Poseidontypus." The statue of Poseidon shown on the coinage, in her opinion, must have risen above the quadrangular structure, from the Imperial Period, located in the inner port of the Lechaion (see: J. W. Shaw, A Foundation in the inner Harbor at Lechaeum, AfA 73 [1969] 370-372 pl. 96). To support her assumption, Walde referred to the text of Pausanias (2.2.3), which describes a sanctuary and bronze statue of Poseidon in Lechaion, and to a local tradition reported by A. S. Georgiades (Les ports de la Grèce dans l'Antiquité qui subsistent encore aujourd'hui [Athènes 1907] $\mathrm{pl} .1,4)$, which relates this structure to "une statue d'airain représentant Poséidon tenant en main le feu du phare au port." However, Pausanias gives no indication of the location of the statue in Lechaion, and the popular tradition mentioned by Walde seems very doubtful being unverifiable, late in date, and curiously similar to one of the descriptions of the Colossus of Rhodes. Moreover, while being conscious of numismatic conventions-which explain the 
seems to concern the location of the statue of Poseidon: it is found on the mole for Pausanias, and in the harbor for the coin. However,


critical edition of Pausanias published in $1794 .{ }^{21} \mathrm{In}$ actuality, the

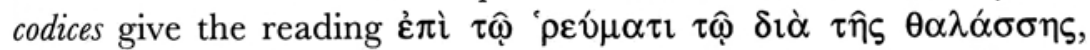
thereby situating the statue on a platform floating in the middle of the harbor. The correction of Facius was accepted by all authors, with the notable exception of W. M. Leake, who suggested correct-

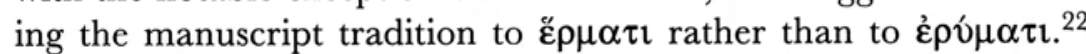
According to Leake, the statue would have been erected on a rock emerging from the seas in the harbor compound. The excavations in the harbor of Kenchreai conducted over several decades by the Universities of Chicago and Indiana have never uncovered a clear trace of it. ${ }^{23}$ Nor have they found the substructures of a semi-circular port. As R. L. Hohlfelder concluded, "Although the Kenchreai bay area today coincides approximately with the semicircular numismatic portrayal of the ancient port, excavations conducted at various points on land and underwater indicate a more linear design for the ancient harbor." 24 The image shown on the coin, therefore, probably should not be taken literally. It's likely that the aesthetic concern of the engraver and the round shape of the coin prevailed over a realistic depiction of the harbor. The double symmetry of the composition (quay/ships, temple/temple), moreover, serves to emphasize the central image: the statue of Poseidon. This seems all the more probable as at least one other monetary series - close in date since on the obverse a portrait of Antoninus similarly appears - is more or less identical to that which we have just studied. Rather than a representation of Poseidon in the center of the reverse side

central position of the statue of Poseidon - we must admit that the configuration of the harbor, such as it appears on our coins, is nothing like that which pertains to the studies, undertaken until now, on the Lechaion (see: R. M. Rothaus, Lechaion, western port of Corinth: a preliminary archaeology and history, OfA 14/3 [1995] 293-306).

21 Jo. Facius, Pausaniae Graeciae Descriptio. I (Leipzig 1794) 184 n. 4

22 W. M. Leake, Travels in the Morea. III (London 1830) 235.

23 The underwater excavations, however, unearthed a few large-sized blocks of poros at the end of the septentrional mole, which could have been used as the base for a colossal statue. See: R. Scranton, J. W. Shaw, and L. Ibrahim, Topography and Architecture, Kenchreai: Eastern Port of Corinth, I (Leiden 1978) 18-19.

24 Hohlfelder, Pausanias 330 . (the statue of the god is visible inside the left distype temple), it is Isis sailing (our series 4) who is depicted. Correctly identified by $\mathrm{K}$. Regling, followed by M. J. Price and B. L. Trell, as well as D. E. Smith, the goddess was not recognized by K. Lehmann-Hartleben, or by R. L. Hohlfelder. ${ }^{25}$ As the statue of Poseidon is visible inside his temple on this series, one cannot support the conclusions of this last author since he explains that the statue of Poseidon had been erected rarely before the visit of Pausanias, instead and in place of that statue, not identified by him, figuring in the center of the other series, which then would be the oldest of the two. ${ }^{26}$ On the other hand, K. Lehmann-Hartleben was probably right to think that the harbor of Kenchreai was decorated with several statues at the time of Antoninus. ${ }^{27}$ It's indeed much more likely to think that the communicative power of these coins, very likely contemporaneous, wanted to present the harbor as placed under the protection of the leading marine divinities, namely Poseidon and Isis. The existence of a third series, this time bearing the image of Aphrodite Euploia, could be considered also, even if no coin of this type is known at present. Finally, is it not possible that Pausanias's description was influenced by the coin itself, which he may have had in his hands? ${ }^{28}$

Modern scholars, concentrating on the central image, have been little interested in the dedications of the two temples located at either end of the harbor. Of the series showing temples with statues of Poseidon, M. Millingen suggests that "celui à droite était probablement dédié à Aesculape et Isis, celui du côté opposé à Vénus." 29

${ }^{25}$ J. Leipoldt, K. Regling, Isis-Religion (1925) 130 and pl. 5.3; M. J. Price, B. L. Trell, Coins and their Cities. Architecture on the ancient coins of Greece, Rome and Palestine (London 1977) 83 fig. 146; and Smith, Egyptian 202-203. Lehmann-Hartleben (Hafenanlagen 238 n. 2) mentions only a "weibliche Gottheit"; and Hohlfelder (Pausania 328 n. 10 and pl. 80c) mentions simply "another deity." Hohlfelder does not seem to know the article by Leipoldt and Regling, or the iconography of Isis sailing.

${ }^{26}$ Hohlfelder, Pausanias 328.

27 Lehmann-Hartleben, Hafenanlagen 238 n. 2.

28 We are not able to support the opinion of L. Castiglione (Isis Pharia [1970] $47)$, since he argues that the composition of this coin corresponded to that of Pharos, and from this deduces that the erection of an exact replica of the Alexandrian sanctuary of Isis and its statue was desired at Corinth-Kenchreai.

29 Millingen, Recueil 47. 
F. Dunand identifies instead the temple of Aphrodite and opposite it, that of Isis. ${ }^{30}$ For M. J. Price and B. L. Trell, the two edifices on the series with Isis sailing are the temples of Isis and Asclepios, while D. E. Smith is content to see there simply a temple of Isis. ${ }^{31}$ Considering the apparent similarities observed between these coins and the account of Pausanias, it's understandable that these authors were tempted to identify the two temples with those mentioned by the Periegete in his description of Kenchreai. If we turn our attention to the visible details on the coins themselves, we note on the series with Isis Pelagia that the left distyle temple houses a statue, in this case that of Poseidon. However, Pausanias mentions only a statue of Poseidon in Kenchreai and does not refer at all to a temple. This discrepancy shows how complicated it is to interpret monetary images on the basis of a literary passage. Since the series with Isis sailing shows the temple of Poseidon on the left side, it is possible to speculate whether the series with Poseidon showed vice versa the Isis temple. The sign that suggests such an attribution is the tree that flanks the left temple on the latter series. M. Millingen identified it with the pine near which Sisyphus found the body of Melikertes, thus seeing an allusion to the Isthmian Games. ${ }^{32}$ But such an interpretation is challenged by the tree's location in Kenchreai, as the pine of Melikertes was cited by Pausanias as being on the road to Megara, near Cromyon (2.1.3). ${ }^{33}$ Moreover, the palm tree- a typical Egyptian motif for the Ancients, and not grown in Greece at the time ${ }^{34}$ - and its proximity to a temple was

${ }^{30}$ Dunand, Culte d'Isis II 159.

31 Price, Trell, Coins and their Cities 82 and 85; Smith, Egyptian Cults 229.

${ }^{32}$ Millingen, Recueil 47-48.

33 The pine tree appears on very many coins in relation to the myth of Melikertes (see among others: Price, Trell, Coins and their Cities figs. 150-151; or Walbank, Aspects of Corinthian Coinage fig. 20.12). More curious is the depiction of a tree on coins representing the temple of Aphrodite on the Acrocorinth. At each end of the foot of the cliff is a building flanked by a tree on the left (see: Walbank, Aspects of Corinthian Coinage fig. 20.9.3; or again, Price, Trell, Coins and their Cities fig. 135). Millingen also identifies this pine as the one of Melikertes, whereas Price relates it to the Peirene fountain.

${ }^{34}$ Except for Rhodes and Crete; see: I. Wallert, Die Palmen im alten Ägypten. Eine Untersuchung ihrer praktischen, symbolischen und religiösen Bedeutung, Münchner Ägyptologische Studien 1 (Berlin 1962) esp. 147-149 regarding the palm tree of the altar of Apollon at Delos. more likely intended to evoke Egypt and one or both of its divine representatives, Isis or Sarapis. ${ }^{35}$ The existence of palm trees on the compound of Isiac sanctuaries is well attested, in particular by the relief of Ariccia and a fresco of Herculanum. ${ }^{36}$ In addition to conferring a certain Egyptianizing atmosphere, the palm tree also suggests the palm branches necessary for officiants, in particular on the occasion of processions like those described by Apuleius at Kenchreai. ${ }^{37}$

As for the buildings shown in three-quarter view-sometimes to the right, sometimes to the left- they do not seem to be equipped with any particular detail that leads to an identification. However, if the will of the communicative power of these coins was to assert the principal marine divinities - the protectors of the Kenchreai port and the trade generated by it-it's tempting to read on the coins two views of the same temple, namely that which was devoted to Aprodite Euploia.

Let us now consider what the Chicago and Indiana archaeological campaigns conducted at Kenchreai may tell us. Was the Sanctu-

${ }^{35}$ On the palm tree at Corinth and its possible connections with the cult of Isis, see: N. Bookidis \& R. S. Stroud, The Sanctuary of Demeter and Kore. Topography and Architecture, Corinth, XVIII/3 (Princeton 1997) 369-370. See in particular the interpretation by the authors of a terracotta antefix decorated with a date palm (FA-509) on the Middle Terrace of the Sanctuary of Demeter as "a further example of syncretism between the cults of Isis and Demeter", and that of three marble palm trees from the lower city of Corinth (AM-14, A-1037 et A-1039). A palm tree appears in an enclosure on a Corinthian issue of Antoninus (Walbank, Aspects of Corinthian Coinage 343 fig. 20.7.2 and 344 n. 40), and again under Marcus Aurelius, Lucius Verus, and Septimius Severus (BMC Corinth 79.617 pl. XX-16, 81.628, pl. $\mathrm{XX}-17,85.650)$, as well as behind a small structure housing a seated figure, preceded by the emperor and priest, on another issue of Marcus Aurelius (Corinth; Oakley South, 09.11.1933, 85).

36 For Ariccia, see: Malaise, Inventaire 58-59 Ariccia 1 and pl. 2; and Lembke, Iseum Campense 174-175 and pl. 3.1. For Herculanum, see: Tran tam Tinh, Herculanum pll. 27-28.

37 See: M. Malaise, Le perséa, l'olivier, le lierre et la palme dans la religion égyptienne tardive, in: T. DuQuesne (ed.), Hermes Aegyptiacus. Egyptological Studies for B. H. Stricker, Discussions in Egyptology, Special Number 2 (Oxford 1995) 141-143. On the Kenchreai procession, see: Apuleius (Méta. XI, 10). A priest carried a palm and a caduceus (attributes of Anubis) in the Isiac procession of the Navigium Isidis, see: Griffiths, Apuleius 198-199. A priest carrying a palm branch is represented on one of the columns of the Iseum Campense, see: S. Bosticco, Musei Capitolini. I monumenti egizi ed egittizzanti (Roma 1952) pl. 7; and Lembke, Iseum Campense 187188 and $\mathrm{pl} .7$. 
ary of Isis, mentioned by Pausanias and most likely represented on our coins, really unearthed there? During the excavation of a partially submerged complex at the west southern end of the harbor of Kenchreai, several panels of opus sectile in glass, arranged in openwork cases, were discovered in an apsed room, and on which several nilotic and harbor scenes, along with some pastoral scenes and hieratic figures representing consuls, philosophers or mythical characters, were depicted. ${ }^{38}$ The purpose of these panels seems to have been for a restoration of the building undertaken during the second half of the 4th century A.D. ${ }^{39}$ For their creators, the building in which they were exhumed could have belonged to the Iseion mentioned by Pausanias, although this is quite difficult to affirm in the absence of any identifying element. ${ }^{40}$ The same archaeologists also believed that they had found an epiclesis of Isis with the term 'Op yí $\alpha$ engraved on the lower part of a marble column, which was uncovered in the remains of a church of Kenchreai. ${ }^{41}$ Again, this remark remains highly hypothetical. ${ }^{42}$

The Isiac coins of Corinth attest to the success met by the cults of Isis and Sarapis in the Peloponnesus during the second and third centuries A.D. The description of Pausanias and most of the Isiaca from Corinth date from the same time. The Isiac divinities were venerated here not only under the ordinary forms most frequently used during the Imperial Period (our types 1 and 4), but also were

${ }^{38}$ L. Ibrahim, R. Scranton, and R. Brill, The Panels of opus sectile in Glass, Kenchreai: Eastern Port of Corinth, II (Leiden 1976) with all previous bibliography. This book was the subject of a critical report by $\mathrm{Ph}$. Bruneau in the REG XCIII (July-December 1980) 551-552, with whom we share the same conclusions. On the nilotic scenes, see: Versluys, Aegyptiaca Romana 217-219 no. 117.

39 In the opinion of L. I. Wente, A Catalog of Glass in the Graeco-Roman Museum of Alexandria, ARCE Newsletter 121 (Spring 1983) 19-22, a study of the glass objects of the Museum of Alexandria, which come for the most part from the city and its surroundings, would reveal the Alexandrian origin of the opus sectile panels with nilotic or harbor decoration, dated to around 350 A.D.

${ }^{4}$ Scranton, Shaw, and Ibrahim, Topography 71-78. Contra this assumption, see among others: Richard M. Rothaus, Corinth: The First City of Greece. An Urban History of Late Antique Cult and Religion, RGRW 139 (Leiden 2000) 71, who prefers to see there, and quite rightly in our opinion, "an elaborate and sumptuously decorated Nymphaeum, certainly worthy of note."

${ }_{41}$ Scranton, Shaw, and Ibrahim, Topography 73 and ph. $125=$ RICIS*102/0201.

42 Even if Isis could sometimes carry this epithet, as at Thessaloniki (RICIS $113 / 0552)$. represented to highlight a much more specific aspects (our types 2 and 3). ${ }^{43}$ As indicated by the iconography of Isis sailing, most frequently used on the reverse of Isiac coinage struck between the reigns of Antoninus and Caracalla, she is incontestably the Lady of the Seas, the Pelagia, who reigned here at the bridge between continental Greece and the Peloponnesus - on the edge of the two gulfs - assuring the trade between the East and the West.

43 This is what Pausanias seems to say also when he mentions the sanctuaries of Isis Pelagia and Isis Aigyptia while going up to Acrocorinth, just as those of Serapis and Serapis of Canopus (II, 4,6). This is why we do not share the opinion of Dunand (Culte d'Isis II 158) when she writes that one can not affirm "qu'on retrouve ainsi sur les monnaies les deux Isis dont parle Pausanias, la Pélagia et l'Égyptienne, car ce type de l'Isis au sistre et à la situle est un type banal." 